\title{
On the behavior of site effects in central Mexico (the Mexican volcanic belt - MVB), based on records of shallow earthquakes that occurred in the zone between 1998 and 2011
}

\author{
A. Clemente-Chavez ${ }^{1}$, F. R. Zúñiga ${ }^{2}$, J. Lermo ${ }^{3}$, A. Figueroa-Soto ${ }^{2}$, C. Valdés $^{4}$, M. Montiel ${ }^{1}$, O. Chavez ${ }^{1}$, and \\ M. Arroyo ${ }^{1}$ \\ ${ }^{1}$ División de Investigación y Posgrado, Facultad de Ingeniería, Universidad Autónoma de Querétaro, Centro Universitario, \\ Cerro de las Campanas s/n, Querétaro, Querétaro, C.P. 76010, México \\ ${ }^{2}$ Centro de Geociencias (CGEO), Juriquilla, UNAM, P.O. Box 1-742, Querétaro, Querétaro, C.P. 76001, México \\ ${ }^{3}$ Instituto de Ingeniería, UNAM, Ciudad Universitaria, Coyoacán, México D.F., C.P. 04510, México \\ ${ }^{4}$ Instituto de Geofísica, UNAM, Ciudad Universitaria, Coyoacán, México D.F., C.P. 04510, México
}

Correspondence to: A. Clemente-Chavez (aclemente09@alumnos.uaq.mx)

Received: 11 March 2013 - Published in Nat. Hazards Earth Syst. Sci. Discuss.: 15 November 2013

Revised: 8 August 2013 - Accepted: 6 April 2014 - Published: 4 June 2014

\begin{abstract}
The Mexican volcanic belt (MVB) is a seismogenic zone that transects the central part of Mexico with an east-west orientation. The seismic risk and hazard of this seismogenic zone has not been studied in detail due to the scarcity of instrumental data as well as because seismicity in the continental regime of central Mexico is not too frequent. However, it is known that there are precedents of large earthquakes $\left(M_{\mathrm{w}}>6.0\right)$ that have taken place in this zone. The valley of Mexico City (VM) is the sole zone, within the MVB, that has been studied in detail. Studies have mainly focused on the ground amplification during large events such as the 1985 subduction earthquake that occurred off coast of Michoacán. The purpose of this article is to analyze the behavior of site effects in the MVB zone based on records of shallow earthquakes (data not reported before) that occurred in the zone between 1998 and 2011. We present a general overview of site effects in the MVB, a classification of the stations in order to reduce the uncertainty in the data when obtaining attenuation parameters in future works, as well as some comparisons between the information presented here and that presented in previous studies.

A regional evaluation of site effects and Fourier acceleration spectrum (FAS) shape was estimated based on 80 records of 22 shallow earthquakes within the MVB zone. Data of 25 stations were analyzed. Site effects were estimated by using the horizontal-to-vertical spectral ratio (HVSR) methodology. The results show that seismic waves
\end{abstract}

are less amplified in the northeast sites of the MVB with respect to the rest of the zone and that it is possible to classify two groups of stations: (1) stations with negligible site amplification (NSA) and (2) stations with significant site amplification (SSA). Most of the sites in the first group showed small $(<3)$ amplifications while the second group showed amplifications ranging from 4 to 6.5 at frequencies of about $0.35,0.75,15$ and $23 \mathrm{~Hz}$. With these groups of stations, average levels of amplification were contrasted for the first time with those caused by the subduction zone earthquakes. With respect to the FAS shapes, most of them showed similarities at similar epicentral distances. Finally, some variations of site effects were found when compared to those obtained in previous studies on different seismicity regions. These variations were attributed to the location of the source.

These aspects help to advance the understanding about the amplification behavior and of the expected seismic risk on central Mexico due to large earthquakes within the MVB seismogenic zone. 


\section{Introduction}

The MVB is related to the subduction of the Rivera and Cocos plates below the continental North American plate (Singh et al., 2007; Ferrari et al., 2012). In general, the regional tectonics in the MVB have shown to be of extensional type with the minimum compressive stress in the north-south direction (Suter et al., 2001). The stress state of the MVB area has been inferred largely from major structures - such as alignments, faults, and barriers of volcanoes and dikes (e.g., Suter et al., 1995) - because of the scarcity of instrumental seismicity data (Zuñiga et al., 2003). Several studies have suggested that due to the morpho-tectonic composition of the MVB, there are significant differences in the behavior of seismic signals originated from subduction earthquakes among sites within the MVB as opposed to other reception sites (e.g., Shapiro et al., 1997; Ferrer-Toledo et al., 2004; Cruz et al., 2009). These studies suggest that the site effects may differ within the entire MVB. However, at present time there are no detailed studies focusing on these characteristics. Most of the studies in the region (e.g., Singh et al., 1988a; Ordaz and Singh, 1992; Chávez-García et al., 1994; SánchezSesma et al., 1995; Singh et al., 1995; Chávez-García and Cuenca, 1996; Reinoso and Ordaz, 1999; Montalvo et al., 2000; Chávez-García and Salazar, 2002) have emphasized the ground response within and around the Valley of Mexico (where Mexico City is located, hereafter referred to as $\mathrm{VM})$.

The MVB is a zone of low seismicity compared to other seismogenic sources in Mexico. Few studies dealing with its seismicity characteristics in this region have been published (e.g., Astiz-Delgado, 1980; Suárez et al., 1994; Suter et al., 1996; Zúñiga et al., 2003; Quintanar et al., 2004). However, earthquakes have occurred in the past within the MVB which caused destruction including the 1568 Jalisco earthquake which had a magnitude $M_{\mathrm{W}}$ estimated between 7.5 and 7.8 (Suárez et al., 1994); the 1912 earthquake occurred in Acambay, State of Mexico, with $M_{\mathrm{w}}=7.0$ (Singh and Suárez, 1987) and the 1920 earthquake which took place near Jalapa, Veracruz with $M_{\mathrm{S}}=6.4$ (Suárez, 1992). These types of earthquakes represent an important risk due to their proximity to urban areas.

Previous studies on seismic signal behavior within the MVB, which have been based on the analysis of small zones of the MVB (mainly in or around the VM) have observed that there is variability in the amplified signal depending on the trajectories of analysis (e.g., Cruz et al., 2009) being significantly higher in the VM (e.g., Singh et al., 1988a, b; Shapiro et al., 1997; Reinoso and Ordaz, 1999). In the VM, amplitudes decrease rapidly toward the north (Figueroa, 1986), and the ground motion is commonly associated with longer durations (Kawase and Aki,1989). The velocity of the seismic waves is slower as they propagate through the MVB, but higher velocities have been recorded in the north section of the MVB in comparison with the south (Shapiro et al.,
1997). Attenuation values show a low seismic quality factor ( $Q) Q\left(Q(f)=98 f^{0.72}\right)$, as compared to the regional $Q$ values $\left(Q(f)=273 f^{0.66}\right)$ (Ordaz and Singh, 1992), determined from analysis of seismic signals recorded at the extremes of a section of the MVB from south to north, including the VM (Singh et al., 2007).

Site effects are attributed to the response of shallow geology. In Mexico, several methods for the evaluation of site effects with the use of ambient noise and earthquake records have been carried out (e.g., Lermo, 1992; Lermo and Chávez-García, 1993, 1994a, 1994b). In particular the socalled standard spectral ratio (SSR) (Borcherdt, 1970) and the horizontal-to-vertical spectral ratio (HVSR) (Lermo and Chávez-García, 1993) have been used. The HVSR method which makes use of ambient noise data, has been employed for seismic microzonation studies worldwide, providing a reliable fundamental frequency (e.g., Nath et al., 2009; Abd ElAal, 2010; Gosar et al., 2010). However, the HVSR method when employing data from earthquake signals, besides the fundamental frequency, allows for the estimation a reliable amplification (Lermo and Chávez-García, 1993). Based on the HVSR method with the use of earthquake data, two types of seismic stations can be identified: (1) rock-ground and (2) soft-ground stations. This is possible since negligible site amplification (NSA) values at sites on rock is expected, while significant site amplification (SSA) values at sites on softground (Castro and Ruíz-Cruz, 2005) should be found. However, SSA have occasionally been observed in rock sites (e.g., Tucker et al., 1984; Castro et al., 1990; Humphrey and Anderson, 1992). This classification of sites has been fundamental in several studies of seismic attenuation models in the world in order to confidently estimate how seismic amplitude decreases with distance (e.g., Joyner and Boore, 1981; Mandal et al., 2009). In Mexico, the evaluation of site effects has also helped to establish reliable attenuation models (e.g., Ordaz et al., 1989; García, 2006; Clemente-Chavez et al., 2012).

Several studies have included stations within the MVB that have been classified as with NSA, but they did not use the seismicity source types analyzed in this paper (e.g., Singh et al., 2006, 2007; Lozano et al., 2009; García et al., 2009), so currently there is no published study based on seismicity records within the MVB for sources also in the MVB. Even when there are seismic stations located within and around this region, which have been identified as having NSA (e.g., Castro and Ruíz-Cruz, 2005; Singh et al., 2006, 2007; García et al., 2009; Lozano et al., 2009), it is necessary to compare the level of amplification of each station due to local sources to the values observed for regional sources.

In this article, the evaluation of site effects and estimates of Fourier Acceleration Spectral (FAS) shapes focusing on the MVB seismogenic zone at regional level are presented for the first time. This was possible due to the existence of a growing number and better quality of seismic stations (broadband seismometers and accelerographs) in the MVB 
Table 1. Earthquakes analyzed in this study.

\begin{tabular}{|c|c|c|c|c|c|c|c|c|}
\hline $\begin{array}{l}\text { Earthquake } \\
\text { No. }\end{array}$ & Date & $\begin{array}{r}\text { Latitude } \\
\left({ }^{\circ} \mathrm{N}\right)\end{array}$ & $\begin{array}{r}\text { Longitude } \\
\left({ }^{\circ} \mathrm{W}\right)\end{array}$ & $\begin{array}{c}H \\
(\mathrm{~km})\end{array}$ & $M^{*}$ & $\begin{array}{l}\text { Epicentral } \\
\text { Location } \\
\text { (State) }\end{array}$ & $\begin{array}{l}\text { Number } \\
\text { Records }\end{array}$ & $\begin{array}{l}\text { Epicentral } \\
\text { Distance } R \\
(\mathrm{~km})\end{array}$ \\
\hline 1 & 18 Mar 1998 & 20.10 & 99.23 & 5 & 4.3 & Hidalgo & 6 & $69-85$ \\
\hline 2 & 27 Apr 1998 & 19.04 & 98.51 & 2 & 4.0 & Puebla & 1 & 13 \\
\hline 3 & 4 Mar 2000 & 18.84 & 98.57 & 4 & 4.1 & Puebla & 3 & $26-110$ \\
\hline 4 & $12 \operatorname{Mar} 2000$ & 20.10 & 99.29 & 5 & 4.1 & Hidalgo & 3 & $134-190$ \\
\hline 5 & 5 Aug 2001 & 20.47 & 103.67 & 10 & 4.3 & Jalisco & 2 & 143 and 180 \\
\hline 6 & 3 Nov 2002 & 19.26 & 98.04 & 2 & 4.0 & Tlaxcala & 2 & 65 and 182 \\
\hline 7 & 16 Nov 2002 & 19.17 & 98.49 & 9 & 4.1 & Puebla & 5 & $18-226$ \\
\hline 8 & 4 Feb 2003 & 18.92 & 98.51 & 2 & 4.1 & Puebla & 2 & 21 and 120 \\
\hline 9 & 28 Apr 2003 & 19.55 & 103.46 & 4 & 4.0 & Jalisco & 2 & 47 and 166 \\
\hline 10 & 16 Nov 2003 & 19.18 & 98.97 & 7 & 4.0 & Distrito Federal & 13 & $11-242$ \\
\hline 11 & 5 Dec 2003 & 19.72 & 101.25 & 7 & 4.3 & Michoacán & 4 & $8-263$ \\
\hline 12 & 15 Dec 2003 & 20.35 & 99.07 & 4 & 4.0 & Hidalgo & 7 & $7-286$ \\
\hline 13 & 7 Oct 2004 & 20.81 & 103.48 & 5 & 4.2 & Jalisco & 2 & 219 and 268 \\
\hline 14 & 5 Jun 2005 & 19.44 & 103.55 & 5 & 4.2 & Colima & 2 & 32 and 157 \\
\hline 15 & 5 Dec 2007 & 18.64 & 102.22 & 4 & 4.1 & Michoacán & 2 & 27 and 153 \\
\hline 16 & 29 Nov 2009 & 19.36 & 103.76 & 5 & 4.0 & Colima & 2 & 50 and 136 \\
\hline 17 & 17 Apr 2010 & 20.38 & 98.96 & 2 & 4.1 & Hidalgo & 8 & $12-251$ \\
\hline 18 & 18 May 2010 & 20.27 & 99.04 & 3 & 4.3 & Hidalgo & 9 & $3-281$ \\
\hline 19 & 18 May 2010 & 20.35 & 98.92 & 5 & 3.6 & Hidalgo & 2 & 44 and 195 \\
\hline 20 & 20 May 2010 & 20.34 & 98.89 & 2 & 3.9 & Hidalgo & 1 & 167 \\
\hline 21 & 3 Oct 2010 & 19.48 & 103.52 & 6 & 4.0 & Jalisco & 3 & $25-203$ \\
\hline 22 & 8 Feb 2011 & 19.73 & 104.51 & 5 & 4.0 & Jalisco & 1 & 147 \\
\hline
\end{tabular}

$M^{*}=$ Magnitude reported by Servicio Sismológico Nacional (SSN) (http://www.ssn.unam.mx/).

zone. We study the behavior of site effects in the MVB zone based on records of shallow earthquakes (data not reported before) that occurred in this region between 1998 and 2011. We furthermore provide a general overview of site effects in the MVB. A classification of the stations is also given to help future studies of attenuation parameters.

Site effect results based on the type of shallow seismicity of this study are compared with results of previous studies (e.g., Singh et al., 2006, 2007; Lozano et al., 2009; Castro and Ruíz-Cruz, 2005). These authors have reviewed only a few stations within or around the MVB based on in-slab seismicity and inter-plate seismicity. None of these studies have focused on showing regional site effect characteristics as presented in this study, much less with earthquakes occurring within the MVB. A discussion of some of the FAS shapes found is also given. Finally, a comparison of these results was made with the amplification levels that García et al. (2009) reported for a zone outside the MVB (an area between the Mexican Pacific coast and the MVB); due to the inter-plate seismicity that occurs in the Mexican Pacific. It has been shown that this inter-plate seismicity represents the greatest seismic hazard for central Mexico.

This study presents the first steps for the analysis of regional seismic hazard and risk due to the shallow seismicity present in the central zone of Mexico.

\section{Data}

A total of 80 records of 22 shallow earthquakes were used (see Table 1); of these, 77 records are of earthquakes with magnitudes between $4.0 \leq M \leq 4.3$ and the three remaining records correspond to two earthquakes of $M<4$. These last three records were included for their contribution to a better evaluation of site effects at DHIG and JUR1 stations (located north of the MVB, see Fig. 1). All the selected earthquakes were recorded at epicentral distances within the range of 3.4 to $286 \mathrm{~km}$ and with depths of $H \leq 10 \mathrm{~km}$ and occurred within the MVB during the period between 1990 and early 2011. The records were provided by the major seismic networks in Mexico (Tables 1 and 2)

For the purpose of obtaining a site effect average for each station, we selected only stations with at least two records. From this group, the first 13 stations in Table 2 were selected (12 seismographic stations and one acelerograph station). All records were converted to acceleration.

The remaining 12 stations in Table 2 (which have a single record) were analyzed trying to form groups of closely spaced stations to get their averages. Nine of these stations are located in the area of VM; and the three remaining stations are located in the states of Colima, Michoacan and Mexico. These nine stations were subgrouped according to the three known geotechnical zones within the VM (lakebed 


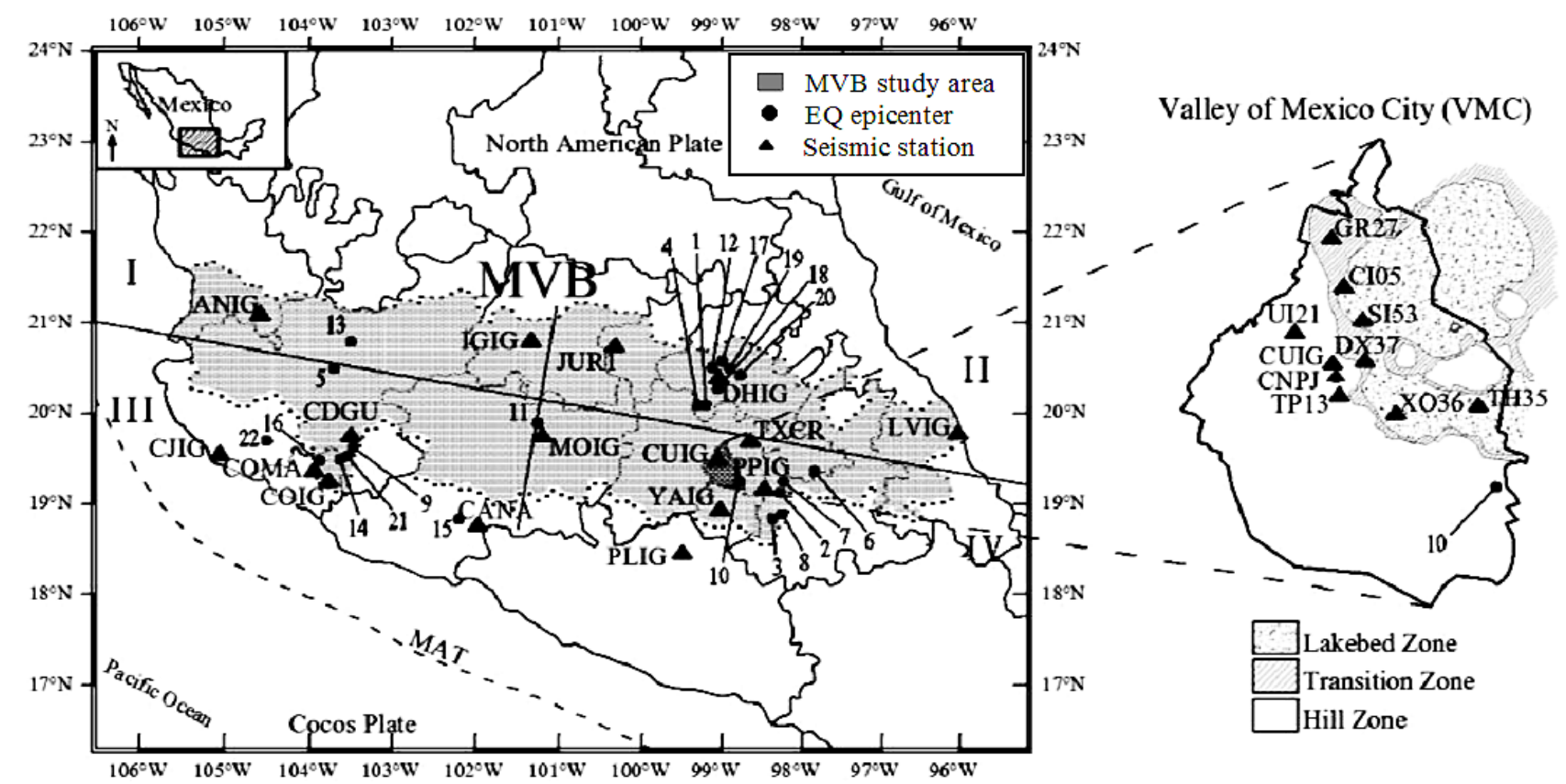

Figure 1. Map of the Mexican volcanic belt (MVB) according to Gómez-Tuena et al. (2005); Location of: epicenters in Table 1, seismic stations in Table 2, and the zone divided in quadrants (solid straight lines) are shown. To the right, the map of the VM located within the Distrito Federal, the stations, and the classification of the three geotechnical zones are also shown.

zone, transition zone and hill zone) (e.g., Reinoso and Ordaz, $1999)$ in order to obtain three representative $H / V$ averages of each zone, $(H / V$ represent the spectral ratio of the component horizontal to vertical. It was not possible to group the last 3 stations due to their geographic dispersion, so the site effects were estimated separately.

The location of earthquakes and the stations are shown in Fig. 1, a division of the zone in four quadrants is also shown and will be discussed later.

\section{Methodology}

The horizontal-to-vertical spectral ratio (HVSR) method (Lermo and Chávez-García, 1993) was used to estimate the site effects. First, the records were visually inspected to select signals that are complete and that had a good signal-to-noise ratio $(\mathrm{S} / \mathrm{N}) \geq 2$.0. A baseline correction was applied to all the signals. For the spectral analysis only the strong ground motion was considered (this according to the criteria recommended by Castro et al., 1997), taking different time-window lengths of 5 to $40 \mathrm{~s}$ starting from the S-wave onset.

Two software packages were used for data processing: Degtra (Ordaz and Montoya, 2000) and Geopsy (Geophysical Signal Database for Noise Array Processing) (SESAME WP05, 2002). The results of these programs were compared because they have a different smoothing function in obtaining FASs, which are the basis to evaluate the $H / V$ spectral ratios.
To determine the HVSR transfer functions, the FASs were calculated for the three components of each record. This is done automatically when estimating the $H / V$ ratio with the Geopsy software. For the calculation of FAS for each selected window, a smoothing function defined in Eq. (1) (Konno and Ohmachi, 1998) was applied with a bandwidth coefficient of $b=40$ and a $5 \%$ cosine taper-window. This type of smoothing function employs a different number of points at low and high frequency; its use is strongly recommended for frequency analysis (Konno and Ohmachi, 1998). The results are very similar in comparison with Degtra software results with a smoothing factor $F_{\mathrm{S}}=6$, which contains another type of smoothing function defined in Eq. (2). A comparison of these results is shown in Fig. 2.

$$
\begin{aligned}
& A_{\mathrm{s}}\left(f, f_{\mathrm{c}}\right)=\left[\frac{\sin \left[\log _{10}\left(f, f_{\mathrm{c}}\right)^{b}\right]}{\log _{10}\left(f, f_{\mathrm{c}}\right)^{b}}\right]^{4}, \\
& {\left[A_{\mathrm{s}}(f)\right]^{2}=\frac{1}{N} \sum[A(f)]^{2},} \\
& f_{1}=f .2^{\left(-\frac{1}{2 F_{\mathrm{S}}}\right)} f_{2}=f .2^{\left(\frac{1}{2 F_{\mathrm{S}}}\right)} .
\end{aligned}
$$

In Eq. (1), $A_{s}\left(f, f_{\mathrm{c}}\right)$ represents the smoothed amplitude; $b, f$ and $f_{\mathrm{c}}$ are coefficients for band width, frequency, and center frequency, respectively. In Eq. (2), $A_{\mathrm{s}}(f)$ represents smoothed amplitude based on frequency $f$. The sum is made in the range defined by frequencies $f_{1}$ and $f_{2}$, of Eq. (3) and $N$ is the number of points between frequencies $f_{1}$ and $f_{2}$. 
Table 2. Classification of the database by seismic network with its stations.

\begin{tabular}{|c|c|c|c|c|c|c|c|}
\hline \multirow[t]{2}{*}{ Institution } & \multirow{2}{*}{$\begin{array}{l}\text { Seismic } \\
\text { network }\end{array}$} & \multirow{2}{*}{$\begin{array}{l}\text { Station } \\
\text { name }\end{array}$} & \multirow{2}{*}{$\begin{array}{l}\text { Site } \\
\text { geology }\end{array}$} & \multicolumn{3}{|c|}{ Number of records } & \multirow[t]{2}{*}{ Instrument type } \\
\hline & & & & /Station & /Network & /Network \% & \\
\hline \multirow{11}{*}{$\begin{array}{l}\text { Servicio Sismológico Nacional } \\
\text { (SSN), Instituto de Geofísica (IG) } \\
\text { Universidad Nacional Autónoma } \\
\text { de México (UNAM) }\end{array}$} & \multirow{11}{*}{$\begin{array}{l}\text { SSN (IG- } \\
\text { UNAM) }\end{array}$} & PPIG & Rock & 10 & \multirow[t]{11}{*}{62} & \multirow{11}{*}{77.5} & \multirow{11}{*}{$\begin{array}{l}\text { Broadband seismographs. Most } \\
\text { of them are composed of a } \\
\text { STS-2 sensor and Q330 } \\
\text { digitizer. Most of their } \\
\text { recordings are at } 80 \text { samples } \\
\text { per second (sps), while a few } \\
\text { are at } 100 \text { sps. }\end{array}$} \\
\hline & & YAIG & Rock & 9 & & & \\
\hline & & PLIG & Rock & 8 & & & \\
\hline & & MOIG & Rock & 7 & & & \\
\hline & & CUIG & Rock & 6 & & & \\
\hline & & DHIG & Rock & 6 & & & \\
\hline & & CJIG & Rock & 5 & & & \\
\hline & & COIG & Rock & 4 & & & \\
\hline & & LVIG & Rock & 3 & & & \\
\hline & & IGIG & Rock & 2 & & & \\
\hline & & ANIG & Rock & 2 & & & \\
\hline $\begin{array}{l}\text { Centro de Geociencias (CGEO) } \\
\text { in Juriquilla, Querétaro, } \\
\text { Campus UNAM }\end{array}$ & $\begin{array}{l}\text { CGEO } \\
\text { (UNAM) }\end{array}$ & JUR1 & Rock & 4 & 4 & 5.0 & $\begin{array}{l}\text { Broadband seismograph. } \\
\text { Composed of a Trillium 120P } \\
\text { sensor and a Taurus digitizer. } \\
\text { All its records are at } 100 \mathrm{sps} .\end{array}$ \\
\hline \multirow{4}{*}{$\begin{array}{l}\text { Instituto de Ingeniería } \\
\text { (II), UNAM }\end{array}$} & \multirow{4}{*}{$\begin{array}{l}\text { II- } \\
\text { (UNAM) }\end{array}$} & CDGU & Rock & 2 & \multirow[t]{4}{*}{5} & \multirow[t]{4}{*}{6.3} & \multirow{4}{*}{$\begin{array}{l}\text { Accelerographs. With Etna } \\
\text { episensor. Their records are at } \\
100,200 \text { or } 250 \mathrm{sps} \text {. }\end{array}$} \\
\hline & & COMA & Rock & 1 & & & \\
\hline & & CANA & Rock & 1 & & & \\
\hline & & TXCR & Rock & 1 & & & \\
\hline \multirow{8}{*}{$\begin{array}{l}\text { Centro de Instrumentación } \\
\text { y Registro Sísmico A.C. } \\
\text { (CIRES) }\end{array}$} & \multirow[t]{8}{*}{ CIRES } & CI05 & Clay & 1 & \multirow[t]{8}{*}{8} & \multirow[t]{8}{*}{10} & \multirow{8}{*}{$\begin{array}{l}\text { Accelerographs. Models SSA-1 } \\
\text { and RAD- } 851 . \text { Most of their } \\
\text { recordings are at } 200 \mathrm{sps} \text {, while } \\
\text { a few are at } 100 \mathrm{sps} \text {. }\end{array}$} \\
\hline & & GR27 & Clay & 1 & & & \\
\hline & & UI21 & Sand & 1 & & & \\
\hline & & DX37 & Clay & 1 & & & \\
\hline & & SI53 & Clay & 1 & & & \\
\hline & & TH35 & Clay & 1 & & & \\
\hline & & TP13 & Sand & 1 & & & \\
\hline & & XO36 & Clay & 1 & & & \\
\hline \multirow[t]{2}{*}{$\begin{array}{l}\text { Centro Nacional de Prevención } \\
\text { de Desastres (CENAPRED) }\end{array}$} & \multirow[t]{2}{*}{ CENAPRED } & \multirow[t]{2}{*}{ CNPJ } & \multirow[t]{2}{*}{ Rock } & \multirow[t]{2}{*}{1} & 1 & \multirow[t]{2}{*}{1.2} & \multirow[t]{2}{*}{$\begin{array}{l}\text { Accelerograph. Model Altus } \\
\text { K2. Its record is at } 100 \mathrm{sps} \text {. }\end{array}$} \\
\hline & & & & & 80 & & \\
\hline
\end{tabular}

The results of both programs did not show significant differences. Each program had advantages according to the available tools. Geopsy software was used to evaluate spectral ratios $H / V$, and Degtra software to estimate FAS shapes separately for each horizontal component.

We obtained HVSR transfer functions for all the records of the 25 stations. For this purpose $H$ was defined as the square average of FAS of the horizontal components. Afterwards, for each group of earthquakes recorded at each station site, $H / V$ averages were calculated with their standard deviations and plotted on a logarithmic scale.

Finally, FASs were obtained for each horizontal component of records of earthquakes with greater azimuthal coverage. This was performed with the aim of qualitatively analyzing the behavior of the shapes and amplitudes in the FASs for different trajectories of seismic wave propagation.

\section{Results and discussion}

Figure 3 shows averages and standard deviations of the $H / V$ spectral ratios for the 13 stations analyzed as well as for the three zones within the VM (Fig. 1) in order to estimate the site effects. Moreover, Table 3 shows all the estimated site effects grouped by quadrants in the MVB. Results are given for the fundamental frequency $\left(f_{\mathrm{o}}\right)$, the amplification factor $\left(A_{\mathrm{o}}\right)$ and values of other peaks in frequencies with smaller amplitudes.

Most of the ratios of Figs. 3 and 4 show a greater and more frequent variability at a frequency of about $0.5 \mathrm{~Hz}$ as compared to other frequencies. This coincides with the observations of Singh et al. (2007) who analyzed inter-plate earthquake data from two stations in order to estimate $Q$ for a strip in the MVB. On the other hand, Table 3 and Fig. 5 show that stations LVIG, DHIG, JUR1 and MOIG can be considered as reference stations to estimate relative amplification in the MVB zone, due to a low $A_{\mathrm{o}}\left(A_{\mathrm{o}}<2.7\right)$, as well as an almost flat level in the $H / V$ spectral ratio.

With the objective of providing a general overview of site effects in the MVB, in Fig. 5 we include the $H / V$ spectral ratio averages shown in Fig. 3, as well as three evaluations of site effects at stations with a single record (COMA, CANA and TXCR). This information is plotted as a function 
Table 3. Results of the estimation of site effects grouped by quadrants in the MVB. It shows the following: fundamental frequency identification $\left(f_{\mathrm{O}}\right)$, amplified factor $\left(A_{\mathrm{O}}\right)$, the classification of the amplification level at each seismic station site, values of other peaks at frequencies with smaller amplitudes and the number of records used in each evaluation of the sites.

\begin{tabular}{|c|c|c|c|c|c|c|c|c|c|c|c|}
\hline $\begin{array}{l}\text { Quadrant } \\
\text { no. }\end{array}$ & $\begin{array}{l}\text { Station name } \\
\text { or zone }\end{array}$ & $\begin{array}{c}f_{\mathrm{o}} \\
(\mathrm{Hz})\end{array}$ & $A_{\mathrm{O}}$ & $\begin{array}{c}\text { Classification } \\
\text { of the site } \\
\text { amplification level }\end{array}$ & $\begin{array}{c}f_{1} \\
(\mathrm{~Hz})\end{array}$ & $A_{1}$ & $\begin{array}{c}f_{2} \\
(\mathrm{~Hz})\end{array}$ & $A_{2}$ & $\begin{array}{c}f_{3} \\
(\mathrm{~Hz})\end{array}$ & $A_{3}$ & $\begin{array}{c}\text { Number } \\
\text { of } \\
\text { Records }\end{array}$ \\
\hline \multirow[t]{2}{*}{ I } & ANIG & 16.58 & 4.97 & $S$ & 0.25 & 3.36 & 0.35 & 3.29 & - & - & 2 \\
\hline & IGIG & 0.75 & 6.20 & S & 23.59 & 5.80 & 14.82 & 5.80 & - & - & 2 \\
\hline \multirow[t]{4}{*}{ II } & JUR1 & 0.37 & 2.52 & $\mathrm{~N}$ & 0.92 & 2.20 & 2.10 & 2.45 & 4.56 & 2.40 & 4 \\
\hline & DHIG & 0.50 & 2.46 & $\mathrm{~N}$ & 0.25 & 2.13 & 0.35 & 1.78 & - & - & 6 \\
\hline & LVIG & 0.45 & 2.23 & $\mathrm{~N}$ & 1.65 & 1.95 & 2.89 & 2.16 & 5.06 & 2.00 & 3 \\
\hline & MOIG $^{*}$ & 0.20 & 2.65 & $\mathrm{~N}$ & 0.13 & 2.43 & 0.40 & 2.31 & 1.00 & 2.07 & 7 \\
\hline \multirow[t]{3}{*}{ III } & $\mathrm{CDGU}$ & 0.35 & 4.02 & S & 8.19 & 2.95 & 9.85 & 3.31 & - & - & 2 \\
\hline & CJIG & 1.94 & 2.26 & $\mathrm{~N}$ & 0.67 & 2.23 & 0.23 & 2.19 & - & - & 5 \\
\hline & COIG & 0.28 & 4.64 & S & 1.30 & 3.72 & 2.17 & 3.37 & - & - & 4 \\
\hline \multirow[t]{7}{*}{ IV } & CUIG & $0.17-0.22$ & $5.05-4.93$ & S & 0.70 & 3.40 & 10.75 & 2.54 & - & - & 6 \\
\hline & PPIG & $12.52-14.01$ & $5.53-5.61$ & S & 0.67 & 4.20 & 0.05 & 4.19 & 0.35 & 4.05 & 10 \\
\hline & YAIG & 0.70 & 3.35 & $\mathrm{~N}$ & 0.40 & 2.75 & 4.05 & 2.37 & - & - & 9 \\
\hline & PLIG & 0.35 & 3.81 & $\mathrm{~N}$ & - & - & - & - & - & - & 8 \\
\hline & HILL & 0.60 & 5.83 & S & 1.07 & 3.98 & - & - & - & - & 3 \\
\hline & TRANSITION & 1.33 & 11.56 & S & 1.07 & 11.11 & 0.33 & 3.82 & 0.13 & 3.16 & 2 \\
\hline & LAKEBED & 0.67 & 9.48 & S & - & - & - & - & - & - & 4 \\
\hline
\end{tabular}

$\mathrm{S}=$ Significant, $\mathrm{N}=$ Neglible. ${ }^{*}$ Considered in quadrant II, due to its behavior in $H / V$ spectral ratio, in addition to its central location in the MVB.

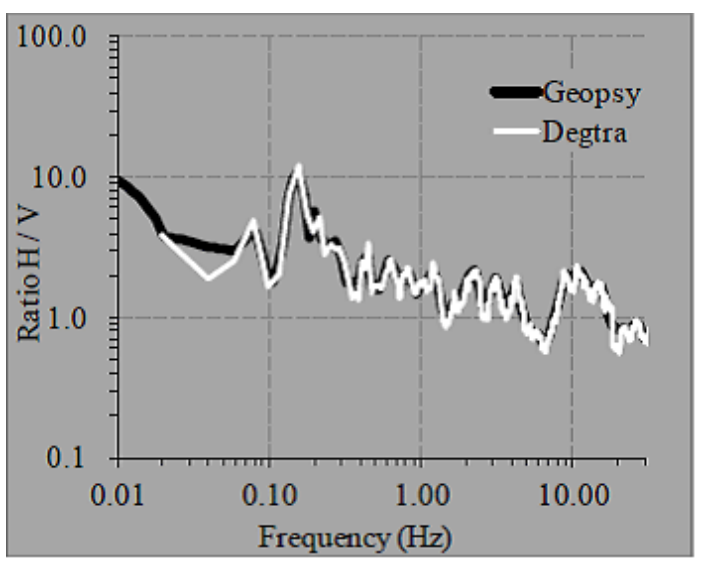

Figure 2. Comparison of $H / V$ results of the Geopsy and Degtra softwares are shown. Observe that the ratios are similar although the smoothing functions are different.

of period and according to its geographical position associated to each site. Information of this type is often used to relate with the structural periods in order to evaluate the expected damage due to an earthquake.

Figure 5 shows the following key points in each MVB quadrant:

1. The sites evaluated in quadrant II indicate lesser amplifications than the sites at other quadrants. On the contrary, the greatest amplifications of seismic signals oc- cur - in decreasing order - at sites in quadrants I, IV and III, with an amplification factor of up to 6.2, mostly at low frequencies of 0.1 to $2 \mathrm{~Hz}$ (or 10 to $0.5 \mathrm{~s}$ );

2. All sites of the four quadrants have up to three peaks with amplitudes of around 2, except for PLIG, which presents a single well-defined peak. This could be a clear difference in site effects for stations within and outside the MVB, since PLIG is regarded as outside the MVB. CJIG station, also outside the MVB, shows similar behavior.

3. Important differences on the averages of site effects for two of the three zones within the VM were identified with respect to those given by Reinoso and Ordaz (1999) in their analysis based on large earthquakes (magnitude between 7.4 and 8.1) of the subduction type. In the transition zone our results are similar to those of Reinoso and Ordaz (1999). On the other hand, in the southern part of the lakebed zone, our results do not show large values (values between 50 and 75) of amplification in the range of 3 to $4 \mathrm{~s}$ as those obtained by these authors for this period. However, our results agree with them in a second peak at approximately the $1.5 \mathrm{~s}$ period with amplification of about 10 .

The results of Table 3 were further used to classify the stations. This classification is consistent with the criteria proposed in previous studies on site effects in Mexico (e.g., 

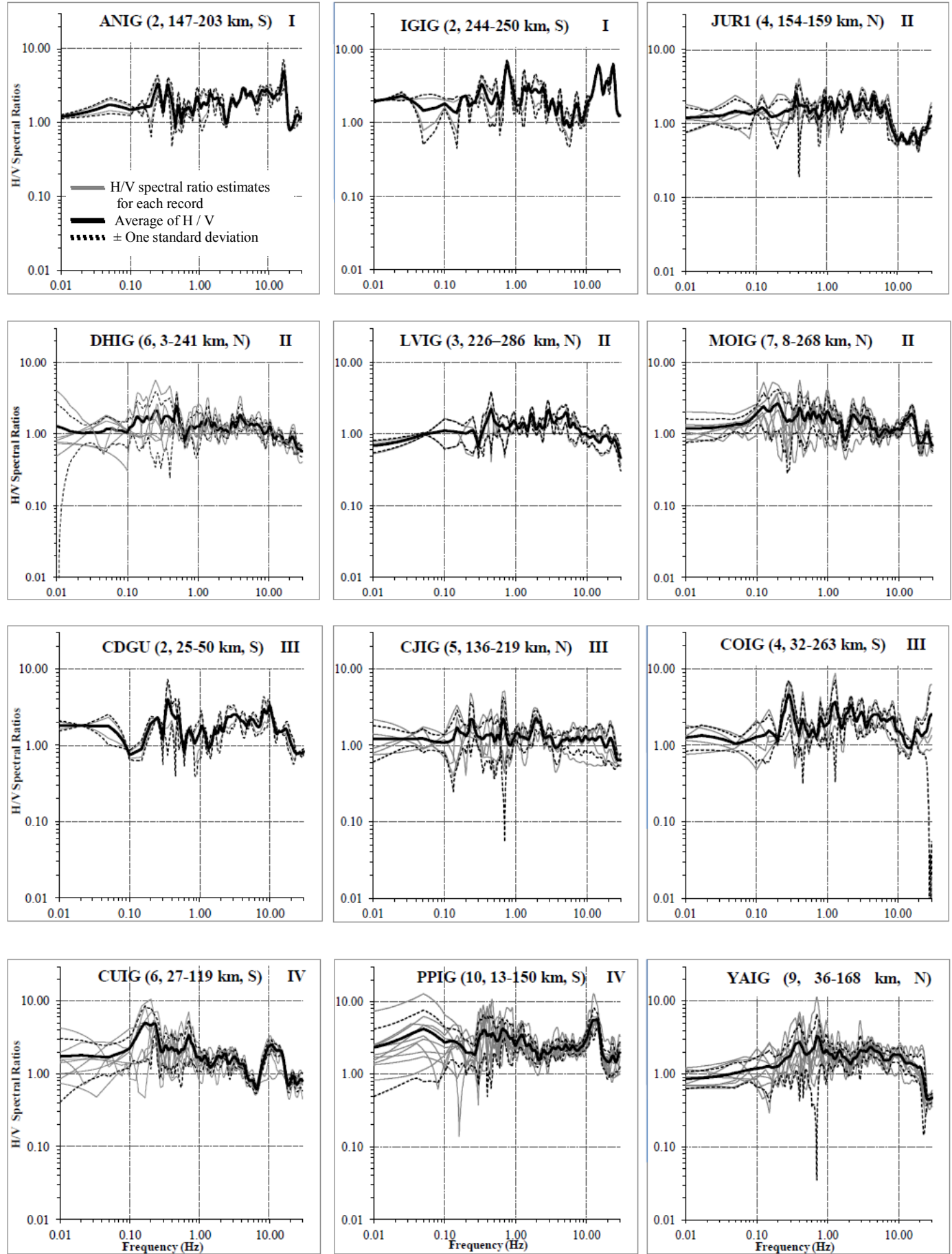

Figure 3. Averages of $H / V$ spectral ratios \pm one standard deviation for all stations are shown. The headers in each graph correspond to the following nomenclature: Station (Number of records, epicentral distance range in $\mathrm{km}$, site classification: $N=$ negligible site amplification or $S=$ significant site amplification) and quadrant number.

Lermo and Chávez-García, 1993; Bard, 1999; Castro and Ruíz-Cruz, 2005; García et al., 2009). They consider a site as having an NSA when $A_{\mathrm{o}}$ is $\leq 2.5-3.0$ at the fundamental frequency $f_{\mathrm{o}}$ (as it occurs for most hard-rock sites) and, conversely, they assign an SSA label to sites with $A_{\mathrm{o}}>3$.
Thus, seven stations (JUR1, DHIG, LVIG, MOIG, CJIG, YAIG and PLIG) present NSA and six (ANIG, IGIG, CDGU, COIG, CUIG and PPIG) have SSA. However, in this study, YAIG and PLIG stations were placed in the group of stations with NSA, even though they showed amplifications between 

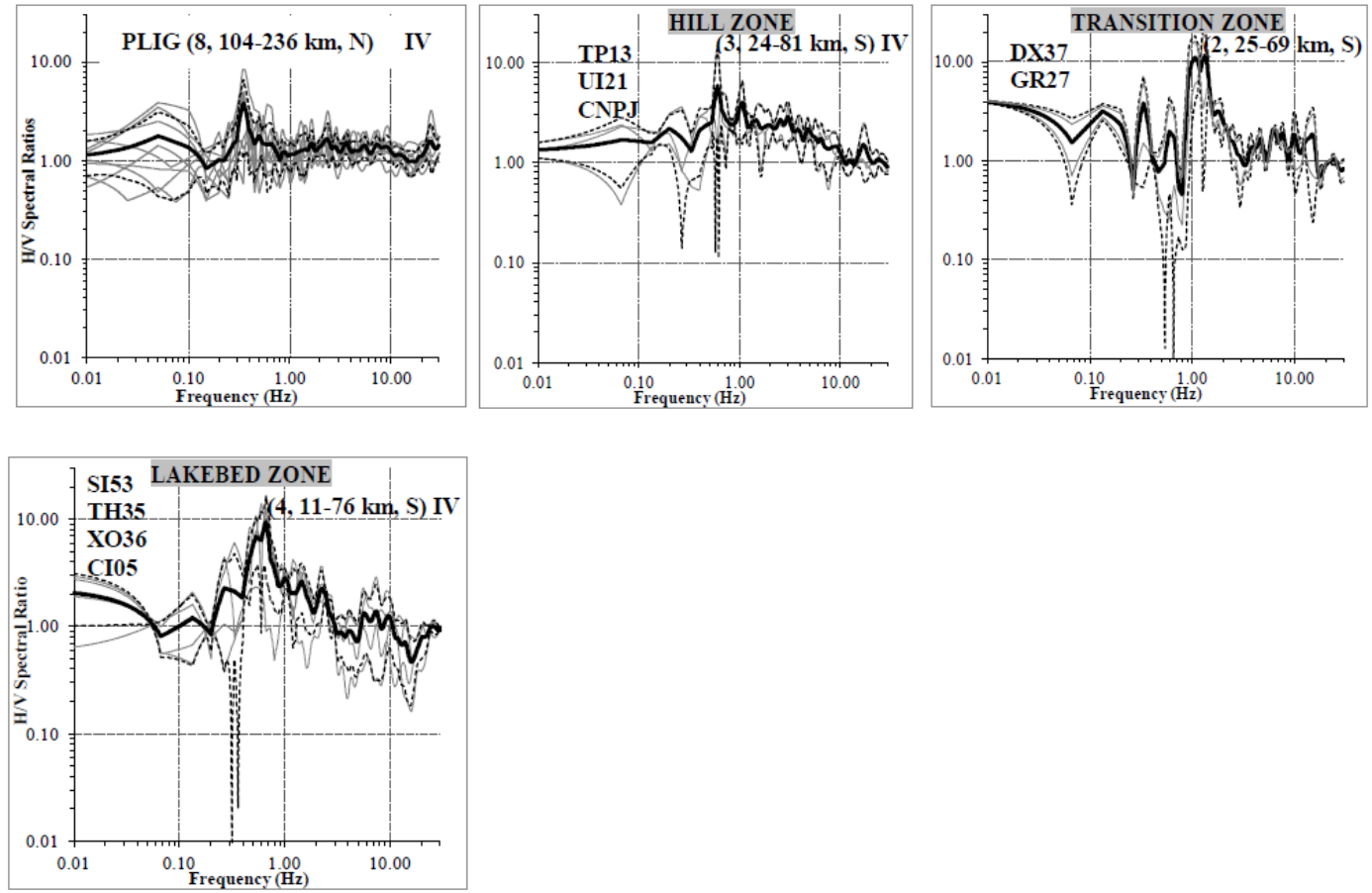

Figure 3. Continuation of Fig. 3. The last three graphs correspond to averages of grouped stations within each geotechnical zone in the VM, this according to the Fig. 1.

3.35 and 3.81. This is because: (a) they have a flat response $(H / V<2)$ for most of the frequency range $(0.01$ to $30 \mathrm{~Hz})$ (see Figs. 3 and 5); and (b) their site amplification values do not significantly alter the average for this group of stations (see Fig. 4).

In order to show the behavior and differences between the two groups of stations (with clasification NSA and SSA), we estimated the averages for both groups. These averages are shown in Fig. 4, which indicate that the main differences lie in the low frequency range of $0.1-1.0 \mathrm{~Hz}$. The averages of the three zones within the VM were not considered in the above averages because they do not represent the general characteristics of the MVB, due to the large amplifications observed for that particular region. Only CUIG station has been included for such averages since its $H / V$ ratio is close to those which represent site effects within the MVB.

Of the stations analyzed in this study it is clear that a low amplification occurs in quadrant II, compared to the rest of the MVB area. The causes of this behavior can be due to the wave velocity in the north being higher than in the southern part of the MVB as reported by Shapiro et al. (1997) for a strip in the zone. These authors associated this low velocity zone with the migration of volcanic activity from north to south, such as reported in Robin (1981). Recently, Singh et al. (2007) reported a higher attenuation, - low $Q-$ in the northern part of the MVB with respect to the forearc (based on the station DHIG). Jödicke et al., 2006 also showed a correlation between this low $Q$ and a low resistivity region.

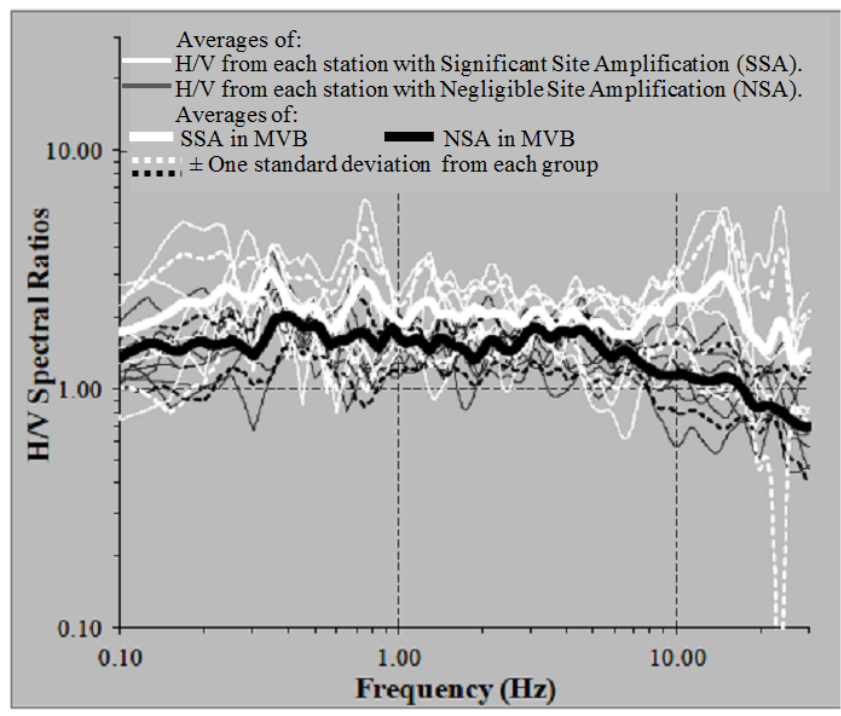

Figure 4. Comparison of the behavior and differences of site amplification between the two groups of stations within the MVB: (1) with SSA and (2) with NSA. Both groups are shown with \pm 1 standard deviation. Observe that the main differences are in the low frequency range of $0.1-1.0 \mathrm{~Hz}$. Averages of all the stations, which form each group, are also shown.

From the above arguments, and according to our results, this behavior might cover a larger area within the MVB, delimited by quadrant II. 

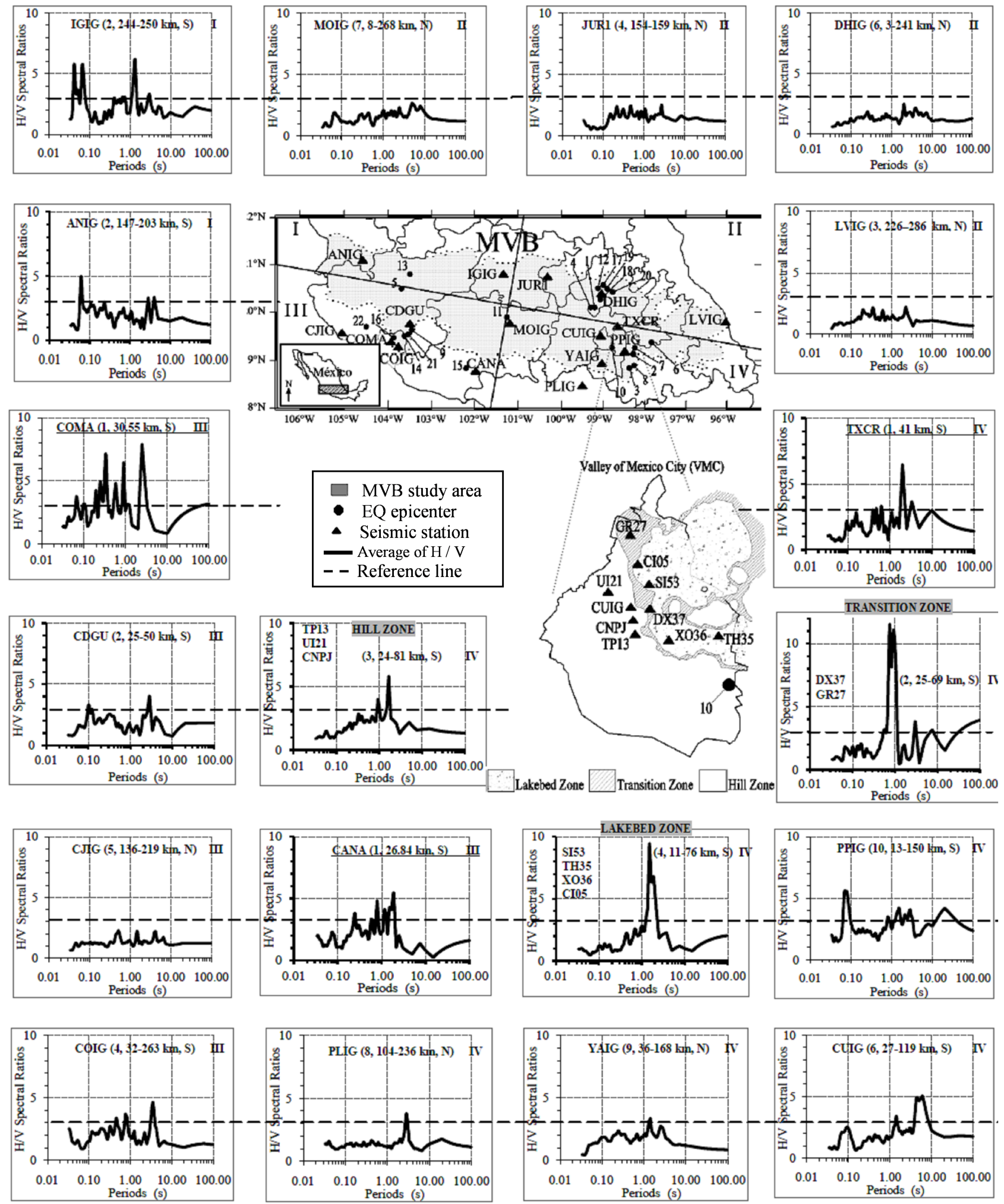

Figure 5. A general overview of site effects in the MVB is shown. Note: a smaller site amplification in the northeast part of the MVB (quadrant II) than those of the other quadrants. (the three stations with a single record: COMA, CANA and TXCR are also included). 
Table 4. Comparisons of $A_{\mathrm{o}}$ and $f_{\mathrm{o}}$ (at sites of stations), reported in previous studies with the results of this study.

\begin{tabular}{llccccc}
\hline \multirow{2}{*}{ Authors } & \multicolumn{3}{c}{ Previous studies } & \multicolumn{2}{c}{ This study } & Increase in $A_{\mathrm{O}}$ \\
\hline Castro and Ruíz-Cruz (2005) & ID Station & $f_{\mathrm{O}}(\mathrm{Hz})$ & $A_{\mathrm{O}}$ & $f_{\mathrm{O}}(\mathrm{Hz})$ & $A_{\mathrm{O}}$ & IAG \\
Singh et al. (2007) & PLIG & $\approx 0.7-0.8$ & $<2.5$ & 0.7 & 3.35 & $34 \%$ \\
& DHIG & $\approx 0.5-0.6$ & $<2.0$ & 0.35 & 3.81 & $91 \%$ \\
Lozano et al. (2009) & CUIG & $0.2-0.7$ & $1.0-3.0^{\prime}$ & $0.17-0.22$ & $5.05-4.93$ & $68 \%$ \\
& PLIG & $\approx 4.0-5.0$ & $<1.5$ & 0.35 & 3.81 & $154 \%$ \\
\hline
\end{tabular}

$(\approx$ results observed in their results).

With respect to FAS, several FAS shapes of the horizontal components were estimated, in order to compare the decay of the amplitudes at each signal frequency with respect to the epicentral distance. This was made for earthquakes 10, 17 and 18 in Table 1, which have the largest number of records in quadrants I, II and IV, despite having a similar magnitude. The locations and FAS shapes of these earthquakes for each site are shown in Fig. 6. From this, the following aspects can be discerned:

1. In quadrants II and IV, the FAS estimated near the source of earthquakes 10 and 18, registered at YAIG and DHIG at distances of 37 and $3 \mathrm{~km}$, respectively, show that their largest amplitudes occur at high frequencies (range 15 to $20 \mathrm{~Hz}$ ). These FASs are similar to the FASs at the source according to the model presented by Haddon (1996);

2. In records at distances greater than $100 \mathrm{~km}$, the highest amplitudes of the FAS shapes are in the range of frequencies from 1 to $10 \mathrm{~Hz}$. This occurs at sites in quadrants I, II and IV, except for YAIG station, which retains its highest amplitudes at high frequencies of around $21 \mathrm{~Hz}$;

3. The values of the maximum amplitudes are very similar between quadrants I, II and IV, except for earthquake 17, recorded at stations IGIG, MOIG and PLIG. It showed greater attenuation at low frequencies $(f \leq$ $6 \mathrm{~Hz}$ ) than at high frequencies (about $15 \mathrm{~Hz}$ );

4. The FAS shapes obtained from each horizontal component for each record showed little variability between them. The largest difference takes place at low frequencies (less than $1 \mathrm{~Hz}$ ).

In Fig. 7, an analogous analysis to that shown in Fig. 6 was made for earthquake no.11 whose epicenter is in the center of the MVB, recorded in three sites located in quadrants II, III and IV. There was a fourth record at MOIG station, which is located at a close distance from the epicenter $(R=8.5 \mathrm{~km})$. The three records are from DHIG, COIG and PLIG stations, with similar epicentral distances (with an average of $R=247 \mathrm{~km}$ ). Key points from this analysis are:
1. The FAS obtained close to the source, from the record in MOIG station, shows its maximum amplitudes at about $1 \mathrm{~Hz}$ as opposed to previous cases, in which their maximum amplitudes appeared at high frequencies (range 15 to $20 \mathrm{~Hz}$ ), for similar epicentral distances ( 3 and $12 \mathrm{~km}$ ) as MOIG station $(R=8.5 \mathrm{~km})$;

2. When the four FAS shapes are superimposed (Fig. 7g), it is clear that the signal at DHIG presents larger attenuation in the 0.3 to $10 \mathrm{~Hz}$ frequency range;

3. To better understand the latter point, the seismograms recorded at the four stations are shown in Fig. 7f. In DHIG record, smaller amplitudes are observed at high frequencies as well as, partially, at low frequencies compared to the other north-south records.

Comparing our results to those from previous studies, we find the following.

Chávez-García and Tejeda-Jácome (2010) presented an evaluation of site effects in Tecoman, Colima, Mexico, an area close to the MVB. These authors used inter-plate earthquake records with epicentral distances of about $100 \mathrm{~km}$. In their results they reported two peaks. The first peak is the fundamental frequency of the site that varies between 0.5 and $0.7 \mathrm{~Hz}$, with an amplification factor that varies between 6 and 8. A second smaller amplitude peak was also shown in their results, with an amplification of about 4 in the range of 1.2 to 2.1 Hz.

Of all the sites analyzed in the present study, the closest to Tecoman is the COIG station. In the present study, three welldefined peaks instead of only two were identified for that site. The first peak corresponds to a fundamental frequency $f_{\mathrm{o}}=0.28 \mathrm{~Hz}$ with amplification factor $A_{\mathrm{o}}=4.64$; these values differ from those reported in the Tecoman study. The two other peaks $\left(f_{1}=1.30 \mathrm{~Hz}\right.$ with $A_{1}=3.72$ and $f_{2}=2.17 \mathrm{~Hz}$ with $A_{2}=3.37$ ) are similar to the second peak values reported in the Tecoman study.

Site amplification averages from the MVB are contrasted for the first time to averages for other trajectories (within the subduction zone) which do not cross the MVB. The latter observations were García et al. (2009). The results of these authors were based on records of inter-plate seismicity that 

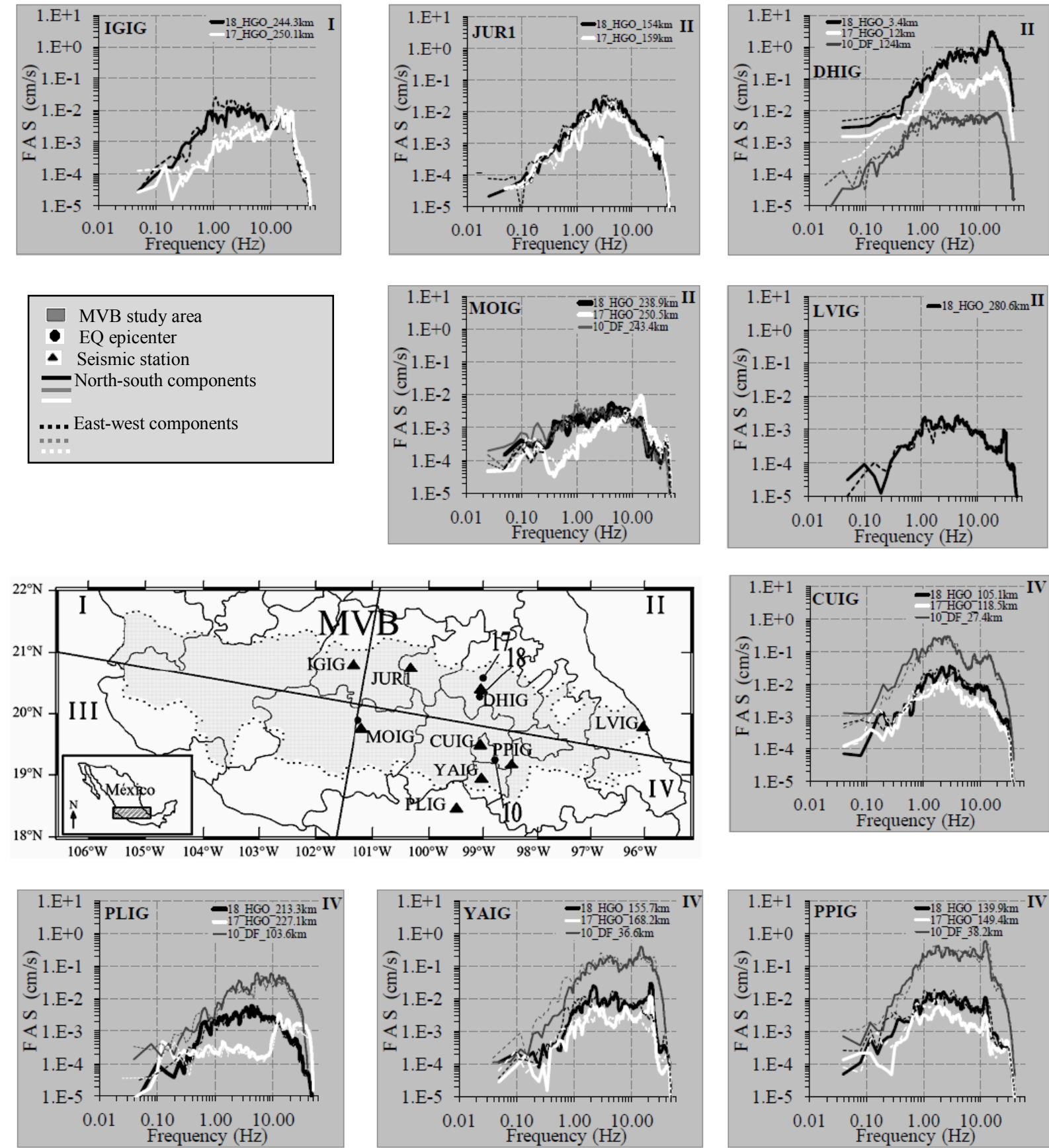

Figure 6. Comparisons of the amplitudes decay among the Fourier acceleration spectra (FAS) of earthquakes 10,17 and 18 ecorded in different places within the MVB are shown (earthquakes of the Table 1 with the largest record number and similar magnitude $M=4$ ). FAS shapes correspond to the horizonal components. The legends in each graph indicate: earthquake number, epicenter location, and epicentral distance. $(\mathrm{HGO}=$ Hidalgo State, $\mathrm{DF}=$ Distrito Federal $)$.

occurred at the Mexican Pacific coast. They obtained $H / V$ averages for two groups of stations with NSA: (a) a group of inland stations and (b) a second group made up of coastal stations (see Fig. 8). Figure 8 shows the differences in site amplification averages of stations on rock at regional level, classified with NSA, outside and inside of the MVB. $A_{\mathrm{s}}$ seen in Fig. 8, an amplification factor of up to 1.5 times at a frequency of $0.36 \mathrm{~Hz}$, is shown for MVB stations with respect to the amplification level of inland stations. On the other hand, when compared with coastal station averages, the behavior is similar. This similarity may be due to the proximity to the seismic source. In frequency ranges from 1 to $5 \mathrm{~Hz}$, the 


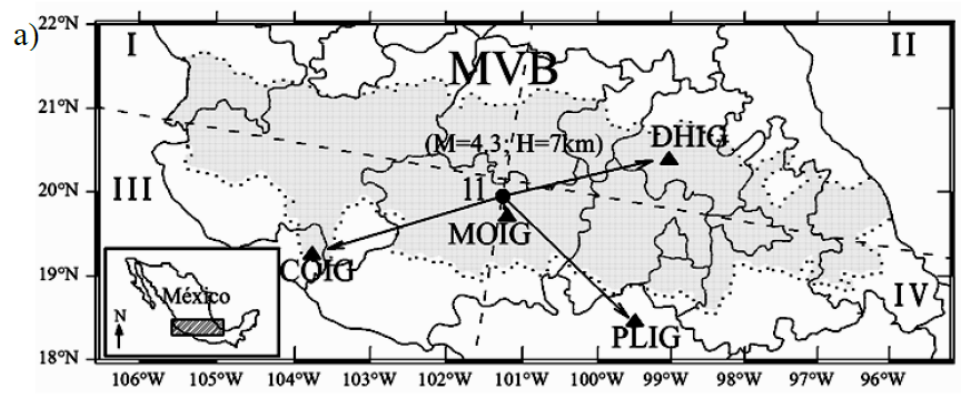

d)

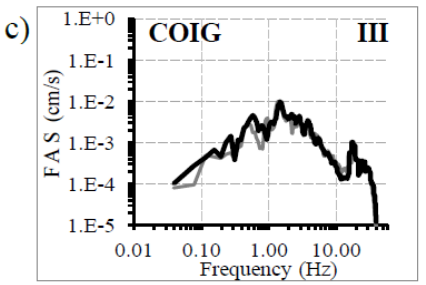

f)

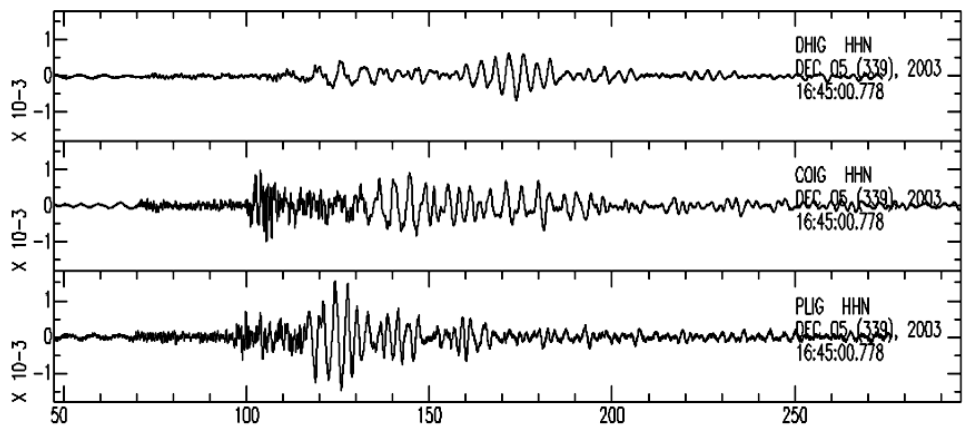

b)

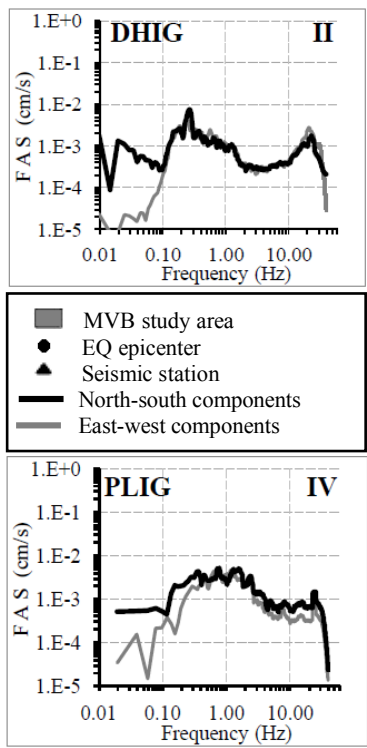

g)

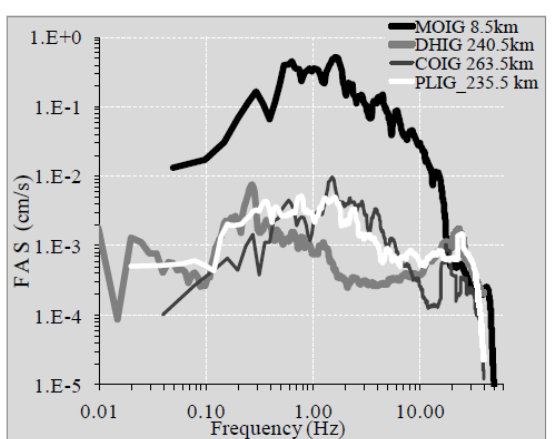

Figure 7. In the panels (a-e) Fourier acceleration spectra (FAS) of earthquake 11 for the station sites MOIG, COIG, PLIG and DHIG (with similar epicentral distances) are shown; In panel (f) seismograms of the north-south component of the COIG, DHIG and PLIG stations (where the DHIG station shows longer periods than the other stations) are also shown; and in panel (g) FAS shapes of the north-south components of the four stations are superimposed, where the greater attenuation is observed at DHIG site (at frequencies of 0.3 to $10 \mathrm{~Hz}$ ) with respect to COIG and PLIG sites.

average levels of amplification at MVB station sites are very similar to the levels of both groups of stations (inland stations and coast stations).

Finally, Table 4 shows other comparisons of $A_{\mathrm{o}}$ and $f_{\mathrm{o}}$ from previous studies (which were based on inter-plate seismicity), with the results of this study. This is for specific stations. In general, the main differences are in $A_{\mathrm{o}}$ with an increment to up a $150 \%$ compared to previous studies.

Regarding the instrumental response correction, it was done based on the generic value of station gain provided by Servicio Sismológico Nacional (SSN) from an instrument calibration sheet (station with STS-2 sensor and Q330 digitalizer). On the other hand, we did some tests for the instrumental response correction (deconvolution process) with two methods, in order to compare and validate our $H / V$ results. First, we performed a deconvolution process (with use of the constant, poles and zeros; from factory information) and second, with the use of the value of station gain; this was performed for the JUR1 station (Trillium 120 TR120-broadband seismograph with similar instrumental flat response to the SSN stations), for which we have the complete information from factory (see technical information in Figueroa et al., 2010). The $H / V$ results are shown in Fig. 9, where we can see that the $H / V$ shapes are identical. This is due to the range of frequency content of the analyzed earthquakes in our study $(0.01-40 \mathrm{~Hz})$ which are within the flat range of the typical instrumental response for broadband seismographs. Thus, we performed the same procedure for all the SSN stations.

We also dealt with the difficulty obtaining reliable $H / V$ results for low frequencies $(<2 \mathrm{~Hz})$ with accelerometer data, which is a common problem for these instruments. This problem was studied in detail by Chávez-García and TejedaJácome (2010), where they reported that accelerometers (like K2) have problems providing good $H / V$ results at frequencies below $2 \mathrm{~Hz}$. However, if the ambient noise level is higher 
a)

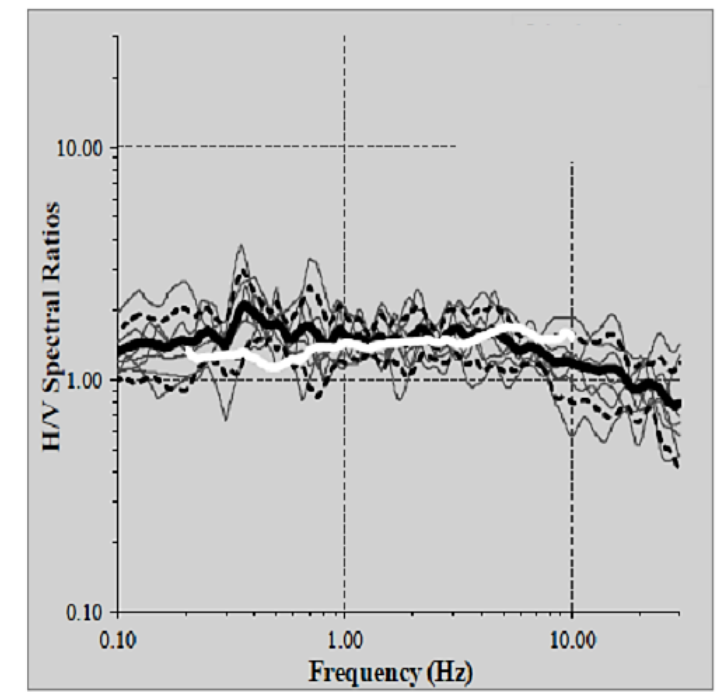

b)

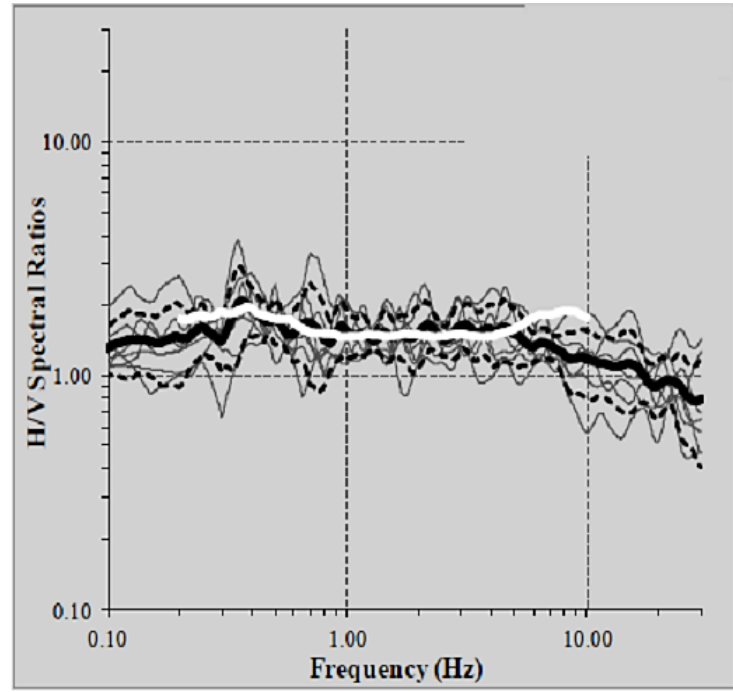

Averages of:

$\mathrm{H} / \mathrm{V}$ of (a) inland and (b) coastal stations with NSA (García et al., 2009)

Average of $\mathrm{H} / \mathrm{V}$ of each station with Negligible Site Amplif
a \pm One standard deviation from the $\mathrm{H} / \mathrm{V}$ average result of the stations with NSA (This study)

Figure 8. Comparisons of averages of site effects with NSA between those reported by García et al. (2009) - sites with trajectories in the subduction zone - and the results of this study are shown. The results of García et al. (2009) are shown for (a) inland stations and (b) coastal stations, this based on records of the inter-plate seismicity of the Mexican Pacific coast. Observe: in (a) an higher amplification factor in MVB sites than the amplification level of inland stations, this of up to 1.5 times at the frequency of 0.36 ; and in (b) the comparison between the MVB sites with averages of the coastal stations, the behavior is similar.

than the amplitude of the electronic noise of the instrument, then the $H / V$ results are excellent. In our study, we have accelerometer data, but these are records at close epicentral distances $(11-81 \mathrm{~km})$ within the Mexico City area, where the ambient noise is much higher than the electronic noise level; furthermore our $H / V$ results are acceptable because we can identify clear peaks for the fundamental frequencies of $0.6-1.33 \mathrm{~Hz}$ (this in last three graphics of the Fig. 3).

Another point worth discussing is the possibility that the different choice of the window employed in our analysis might bias the estimation of the fundamental frequency, in particular with reference to the results shown in Table 4 . Thus, we performed a test with two different windows. We selected only the S-wave trend, with the criteria according to Castro et al. (1997), and compared it to our results from the whole record. The record used was the same from JUR1 station shown in Fig. 9. The $H / V$ results are displayed in Fig. 10. Using an S-wave window alone as opposed to the complete record, we can see that both show the same frequency peaks; the only difference being lower amplitudes at low frequencies. This effect is similar to the effect reported by Parolai and Richwalski (2004) when the choice window is different.

\section{Conclusions}

The Mexican volcanic belt (MVB) is a seismogenic zone that has not been studied in detail in terms of its hazard. This is due to the scarcity of data and the low seismicity in the continental regimen of central Mexico. However, there are precedents of large earthquakes $\left(M_{\mathrm{w}}\right.$ magnitude greater than 6.0) within the MVB. In this study, seismic data from this seismogenic zone were gathered in order to advance the understanding about the expected regional hazard and seismic risk in central Mexico. Eighty records of 22 shallow earthquakes (obtained from 25 stations belonging to the main seismic networks of Mexico during the last 13 years) that occurred within the MVB zone were used to determine site effects and Fourier Acceleration Spectra (FAS). The purpose of this study was to show a general overview of the behavior of site effects in the zone, a classification of seismic stations and to compare with previous studies.

In general, our study yielded the following results:

1. A difference in the level of amplification in the MVB zone was identified. Our results show that site effects in the northeastern part of the MVB present a lesser level of amplification compared to the rest of the zone. This difference coincides with the results of Shapiro et al. (1997) in their study of a strip (north to south) of the MVB across the Valley of Mexico. However, in the present study the results showed that this 


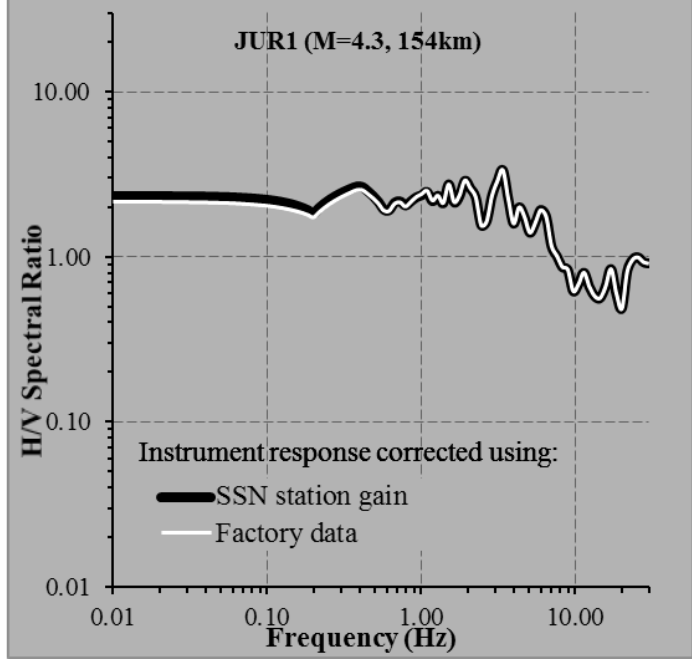

Figure 9. Example of instrumental response correction with two methods: SSN station gain and factory data. The $H / V$ results show identical shapes. The earthquake record used corresponds to the number 18 of the Table 1 with magnitude 4.3 and epicentral distance of $154 \mathrm{~km}$.

behavior covers a greater area of the MVB, corresponding to approximately a quarter of the total MVB area. The average $H / V$ spectral ratios indicate an amplification factor of 2.5 at a frequency of $0.38 \mathrm{~Hz}$. On the other hand, the attenuation of the signals was analyzed qualitatively with FAS shapes to examine the difference in behavior (e.g., frequency ranges for the maximum amplitudes) between different propagation trajectories within the MVB. FAS shapes obtained for the horizontal component records showed a uniform behavior within the MVB, mainly for frequencies $f \geq 1 \mathrm{~Hz}$. However, only one trajectory showed greater attenuation in the northeast part of the MVB. This trajectory starts from the center to the northeast of the zone (see Fig. 7).

2. From the 13 stations on rock sites analyzed, two groups were identified: (1) seven stations with negligible site amplification (NSA) and (2) six stations with significant site amplification (SSA). The first group of stations in general showed amplification factors of 4 to 6.5 at frequencies of about $0.35,0.75,15$ and $23 \mathrm{~Hz}$. From this classification, the first group shows an amplification average similar to the sites analyzed by García et al. (2009) for coastal stations, which were also classified as negligible.

3. NSA and SSA average levels of amplification based on shallow seismicity within the MVB region are analyzed for the first time. We observed amplification differences with respect to the zones outside of the MVB (in particular between the Mexican Pacific coast and the MVB). The most important difference is that in the MVB there

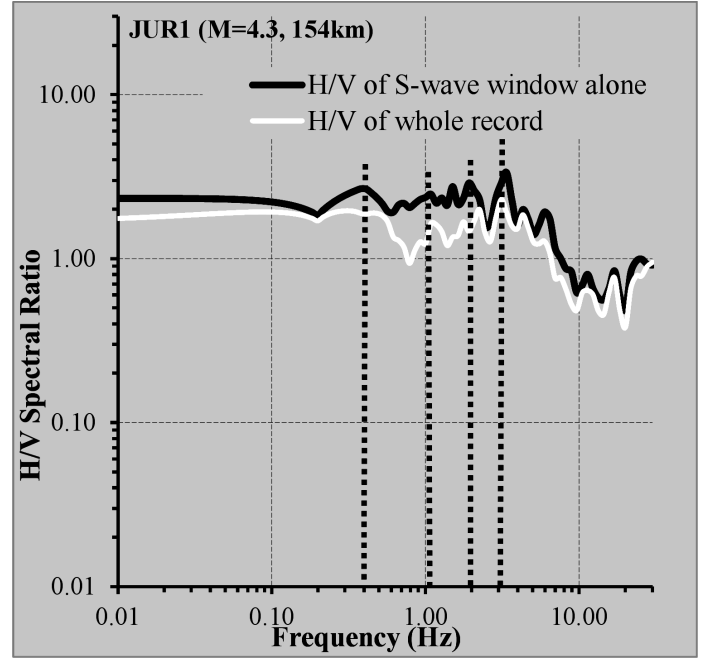

Figure 10. Comparison of $H / V$ results with the use of different window longitude to analysis. The dotted lines show the same peaks at same frequencies in both $H / V$ shapes.

is an amplification of up to 1.5 times more than that found by García (2009) for the Pacific coast in the frequency of $0.36 \mathrm{~Hz}$. This result highlights the relevance of further studying the hazard within the MVB.

Finally, the dependence of site effects results on the characteristics of the source was analyzed. Variations of site effects were found when compared to those obtained in previous studies on different seismicity regions. These variations were attributed to the location of the source. Moreover, we identified more than one peak as the fundamental frequency (we attribute such behavior as typical of the MVB), as opposed to previous studies, in which only one peak was identified.

Acknowledgements. The authors are grateful to CONACYT, Engineering Institute-UNAM, Geosciences Center-UNAM, Institute of Geophysics-UNAM, CIRES and CENAPRED for their support and collaboration in this research. In particular to Mario Gustavo Ordaz Schroeder for his help in obtaining the data. Finally, Alejandro Clemente-Chavez wants to thank CONACYT-Mexico for this funded support for his $\mathrm{PhD}$ studies under the project number 227579 .

\section{Edited by: T. Glade}

Reviewed by: three anonymous referees

\section{References}

Abd El-Aal, A. K.: Ground motion prediction from nearest seismogenic zones in and around Greater Cairo Area, Egypt, Nat Hazards Earth Syst. Sci., 10, 1495-1511, doi:10.5194/nhess-101495-2010, 2010 
Astiz-Delgado, L. M.: Sismicidad en Acambay, Estado de México, El temblor del 22 de febrero de 1979, B.Sc. Thesis Universidad Nacional Autónoma de México, Mexico City, 130 pp., 1980.

Bard, P.-Y.: Microtremor measurements: a tool for site effect estimation?, State-of-the-art paper, Second International Symposium on the Effects of Surface Geology on seismic motion, Yokohama, 1-3 December 1998, edited by: Irikura, Kudo, Okada \& Sasatani, Balkema, Rotterdam, 3, 1251-1279, 1999.

Borcherdt, R. D.: Effects of local geology on ground motion near San Francisco Bay, Bull. Seism. Soc. Am., 60, 29-61, 1970.

Castro, R. R. and Ruíz-Cruz, E.: Stochastic Modeling of the 30 September $1999 M_{\mathrm{W}} 7.5$ Earthquake, Oaxaca, Mexico, Bull. Seism. Soc. Am., 95, 2259-2271, 2005.

Castro, R. R., Anderson, J. G., and Singh, S. K.: Site response, attenuation and source spectra of $\mathrm{S}$ waves along the Guerrero, México, subduction zone, Bull. Seism. Soc. Am., 80, 1481$1503,1990$.

Castro, R. R., Mucciarelli, M., Pacor, F., and Petrungaro C.: S-wave site response estimates using horizontal-to-vertical spectral ratios, Bull. Seism. Soc. Am., 87, 256-260, 1997.

Chávez-García, F. J., and Cuenca, J.: Site effects in Mexico City urban zone. A complementary study, Soil Dyn. Earthquake Eng., 15, 141-146, 1996.

Chávez-García, F. J. and Salazar, L.: A model to explain site response at Mexico City, Bull. Seism. Soc. Am., 92, 3087-3101, 2002.

Chávez-García, F. J. and Tejeda-Jácome, J.: Site response in Tecoman, Colima, Mexico-I: Comparison of results from different instruments and analysis techniques, Soil Dyn. Earthquake Eng., 30, 711-716, 2010.

Chávez-García, F., Sánchez-Sesma, F. J., Campillo, M., and Bard, P.-Y.: El terremoto de Michoacán de Septiembre de 1985: efectos de fuente, trayecto y sitio, Física de la Tierra, 6, 157-200, 1994.

Clemente-Chavez, A., Arroyo, G., Moisés, Zúñiga Ramón, Figueroa Ángel, Pérez Miguel A., and López Carlos S.: Relación de atenuación del movimiento del suelo para la aceleración máxima (PGA) sobre el Cinturón Volcánico Mexicano (MVB); análisis por trayectoria: Guerrero-Querétaro, Revista de Ingeniería Sísmica, 87, 67-93, 2012.

Cruz, J. H., Chávez, G. F., and Furumura, T.: Differences in attenuation of ground motion perpendicular to the mexican subduction zone between Colima and Guerrero: An explanation based on numerical modeling, Bull. Seism. Soc. Am., 99, 400-406, 2009.

Ferrer-Toledo, H., Chávez-García, F., and Cárdenas-Soto, M.: Ground motion in Central Mexico. Path effects due to the Transmexican Volcanic Belt, 13th World Conference on Earhquake Engineering, Vancouver, B.C., Canada, 1-6 August, 13 WCEE, Vancouver, BC, Canada, paper no. 948, 2004.

Ferrari, L., Orozco-Esquivel, T., Manea V., and Manea, M.: The dynamic history of the Trans-Mexican Volcanic Belt and the Mexico subduction zone, Tectonophysics, 522/523, 122-149, 2012.

Figueroa, J.: Isosistas de grandes temblores ocurridos en la República Mexicana, Serie Amarilla del Instituto de Ingeniería, Universidad Nacional Autónoma de México, México, DF, 1986.

Figueroa, A., Clemente-Chávez, A., and Zúñiga, R.: Deconvolución de sismogramas digitales y determinación del ruido sísmico para el sismógrafo Trillium 120 instalado en el campus Juriquilla de la UNAM, Bol-e Órgano de comunicación electrónica del Centro de Geociencias de la UNAM,
6, http://www.geociencias.unam.mx/ bole/bole/page1/page29/ files/fe7b6457275b6460b9f86be2f9bfba89-0.html, 2010.

García, D.: Estimación de parámetros del movimiento fuerte del suelo para terremotos interplaca e intraslab en México central, $\mathrm{PhD}$ thesis, Universidad Complutense de Madrid, Spain, 2006.

García, D., Singh, S. K., Herraiz, M., Ordaz, M., Pacheco, J. F., and Cruz-Jiménez, H.: Influence of subduction zone structure on coastal and inland attenuation in Mexico, Geophys. J. Int., 179, 215-230, 2009.

Gómez-Tuena, A., Orozco-Esquivel, T., and Ferrari, L.: Petrogénesis ígnea de la faja volcánica transmexicana, Boletín de la Sociedad Geológica Mexicana, Vol. Conmemorativo del Centenario, Temas selectos de la Geología Mexicana, Tomo LVII, Revista BSGM, 227-283, 2005.

Gosar, A.: Site effects and soil-structure resonance study in the Kobarid basin (NW Slovenia) using microtremors, Nat. Hazards Earth Syst. Sci., 10, 761-772, doi:10.5194/nhess-10-761-2010, 2010.

Haddon, R. A. W.: Earthquake Source Spectra, Bull. Seism. Soc. Am., 86, 1300-1313, 1996.

Humphrey, J. R. and Anderson, J. G.: Shear-wave attenuation and site response in Guerrero, Mexico, Bull. Seism. Soc. Am., 82, 1622-1645, 1992.

Jödicke, H., Jording, A., Ferrari, L., Arzate, J., Mezger, K., and Rüpke, L.: Fluid release from the subducted Cocos plate and partial melting of the crust deduced from magnetotelluric studies in Southern Mexico: Implications for the generation of volcanism and subduction dynamics, J. Geophys. Res., 111, 1-22, 2006.

Joyner, W. B. and Boore, D. M.: Peak horizontal acceleration and velocity from strong-motion records including records from the 1979 imperialvalley, California, earthquake, Bull. Seism. Soc. Am., 71, 2011-2038, 1981.

Kawase, H. and Aki, K.: A study on the response of a soft basin for incident $S, P$, rayleigth waves with special reference to the long duration observed in Mexico City, Bull. Seism. Soc. Am., 79, 1361-1382, 1989.

Konno, K. and Ohmachi, T.: Ground-motion characteristics estimated from spectral ratio between horizontal and vertical components of microtremor, Bull. Seism. Soc. Am., 88, 228-241, 1998.

Lermo, J.: Observaciones de Microtremores y su aplicación en Ingeniería Sísmica. Tesis de Maestría, Facultad de Ciencias, UNAM, Mexico City, 1992.

Lermo, J. and Chávez-García, F. J.: Site effect evaluation using Spectral ratios with only one station, Bull. Seism. Soc. Am., 83, 1574-1594, 1993.

Lermo, J. and Chávez-García, F. J.: Are microtremors useful in site response evaluation?, Bull. Seism. Soc. Am., 84, 1350-1364, 1994a.

Lermo, J. and Chávez-García, F. J.: Site effect evaluation at Mexico City: dominant period and relative amplification from strong motion and microtremor records, Soil Dyn. Earthquake Eng., 13, 413-423,1994b.

Lozano, L., Herreaiz, M., and Singh, S. K.: Site effect study in central Mexico using $H / V$ and SSR techniques: Independence of seismic site effects on source characteristics, Soil Dyn. Earthquake Eng., 29, 504-516, 2009.

Mandal, P., Kumar, N., Satyamurthy, D., and Raju I.P.: Groundmotion attenuation relation from strong-motion records of the 
$2001 M_{\mathrm{W}} 7.7$ Bhuj earthquake sequence (2001-2006), Gujarat, India, Pure Appl. Geophys., 166, 451-469, 2009.

Montalvo, J. C., Reinoso E., and Sánchez-Sesma, F. J.: Diferencias en el movimiento sísmico observado en la zona de lomas, Ciudad de México, Memorias del primer simposio de riesgos geológicos y ambientales en la ciudad de México, Ciudad Universitaria, México, 2000.

Nath, S.K. and Thingbaijam, K. K. S.: Seismic hazard assessment a holistic microzonation approach, Nat. Hazards Earth Syst. Sci., 9, 1445-1459, doi:10.5194/nhess-9-1445-2009, 2009.

Ordaz, M. and Montoya, C.: DEGTRA A4 Ver. 5.4.0, Instituto de Ingeniería, Universidad Nacional Autónoma de México, Mexico City, 2000.

Ordaz, M. and Singh, S. K.: Source spectra and spectral attenuation of seismic waves from mexican earthquakes, and evidence of amplification in the hill zone of Mexico City, Bull. Seism. Soc. Am., 82, 24-43, 1992.

Ordaz, M., Jara, J. M., and Singh, S. K.: Riesgo sísmico y espectros de diseño en el Estado de Guerrero, Mem. VIII Congr. Nac. Ing. Sísmica, Acapulco, México, 16-19 Noviembre, D40-D56, 1989.

Parolai, S. and Richwalski, S. M.: The Importance of Converted Waves in Comparing $H / V$ and RSM Site Response Estimates, Bull. Seism. Soc. Am., 94, 304-313, 2004.

Quintanar, L., Rodríguez-González, M., and Campos-Enríquez, O.: A Shallow Crustal Earthquake Doublet from the Trans-Mexican Volcanic Belt (Central Mexico), Bull. Seism. Soc. Am., 94, 845855, 2004.

Reinoso, E. and Ordaz, M.: Spectral ratios for Mexico City from free-field recordings, Earthquake Spectra, 15, 273-95, 1999.

Robin, C.: Relations volcanologie-magmatologie-géodynamique: application au passage entre volcanismes alcalin et andésitique dans le sud mexicain, Thése de doctorat, Université de ClermontFerrand II, Clermont-Ferrand, 1981.

Sánchez-Sesma, F. J., Pérez-Rocha, L. E., Rodríguez-Zúñiga, J. L., and Flores-Cruz, F.: Efectos de sitio en la ciudad de México a 10 años de los sismos de 1985, La Ingeniería Civil a 10 años de los sismos de 1985, Mexico DF, Simposio Internacional, Septiembre 1995, 56-70, 1995.

SESAME WP05: Site effects assessment using ambient excitations. Optimum deployment strategy for array measurements. European Commission - Research General Directorate Project No. EVG1 CT 2000-00026 SESAME. SESAME European research project WP05- Deliverable D07.05, Geopsy was developed by Laboratoire de Géophysique Interne et Tectonophysique (LGIT) Grenoble, France and University of Potsdam, Germany, 2002.

Shapiro, N. M., Campillo, M., Paul, A., Singh, S. K., Jongmans, D., and Sánchez-Sesma, F. J.: Surface-wave propagation across the Mexican Volcanic Belt and the origin of the long- period seismicwave amplification in the Valley of Mexico, Geophys. J. Int., 128, 151-166, 1997.
Singh, S. K. and Suárez, G.: Overview of the seismicity of Mexico with emphasis on the September 1985 Michoacan earthquake, in: Cassaro, M. A. and Martínez Romero, E., The Mexico Earthquakes-1985: Factors Involved and Lessons Learned, Proc. Int. Conf. Am. Civil Eng. Soc. Am. Assoc. Civ. Eng, Washington, DC, 7-18, 1987.

Singh, S. K., Mena, E., and Castro, R.: Some aspects of the 19 September 1985 Michoacan earthquake and ground motion amplification in and near Mexico City from strong motion data, Bull. Seism. Soc. Am., 78, 451-477, 1988a.

Singh, S. K., Lermo, J., Domínguez, T., Ordaz, M., Espinosa, J. M., Mena, E., and Quass, R.: A study of amplification of seismic waves in the valley of Mexico with respect to a hill zone site, Earthquake Spectra, 4, 653-673, 1988b.

Singh, S. K., Quaas, R., Ordaz, M., Mooser, F., Almora, D., Torres, M., and Vázquez, R.: Is there truly a "hard" rock site in the Valley of Mexico?, Geophys Res. Lett., 22, 481-484, 1995.

Singh, S. K., Pacheco, J. F., García, D., and Iglesias A.: An Estimate of shear-wave Q of the mantle wedge in Mexico, Bull. Seism. Soc. Am., 96, 176-187, 2006.

Singh, S. K., Iglesias, A., García, D., Pacheco, J. F., and Ordaz, M.: $\mathrm{Q}$ of Lg waves in the Central Mexican Volcanic Belt, Bull. Seism. Soc. Am., 97, 1259-1266, 2007.

Suárez, G.: El sismo de Jalapa del 3 de Enero de 1920, Revista Sociedad Mexicana de Ingeniería Sísmica (SMIS), 42, 3-15, 1992.

Suárez, G., García-Acosta, V., and Gaulon, R.: Active crustal deformation in the Jalisco block, Mexico: evidence for a great historical earthquake in the 16th century, Tectonophysics, 234, 117127, 1994.

Suter, M., Carrillo, M., López, M., and Farrar, E.: The Aljibes halfgraben-active extension in the transition zone between the Trans-Mexican volcanic belt and the southern basin and range, Mexico, Geol. Soc. Amer. Bull., 107, 627-641, 1995.

Suter, M., Carrillo-Martínez, M., and Quintero-Legorreta, O.: Macroseismic study of shallow earthquake in the central and eastern parts of Trans-Mexican Volcanic Belt, Mexico, Bull. Seism. Soc. Am., 86, 1952-1963, 1996.

Suter, M., López-Martínez, M., Quintero-Legorreta, O., and Carrillo-Martínez, M.: Quaternary intra-arc extension in the central Trans-Mexican volcanic belt, Geol. Soc. Amer. Bull., 113, 693-703, 2001.

Tucker, B. E.,. King, J. L., Hatzfeld, D., and Nersesov I. L.: Observations of hard-rock sites, Bull. Seism. Soc. Am., 74, 121-136, 1984.

Zúñiga, F. R., Pacheco, J. F., Guzmán-Speziale, M., Aguirre-Díaz, G. J., Espíndola, V. H., and Nava, E.: The Sanfandila earthquake sequence of 1998, Queretaro, Mexico: activation of an undocumented fault in the northern edge of central Trans-Mexican Volcanic Belt, Tectonophysics, 361, 229-238, 2003. 